\title{
MELITAC 12.1 Peptide Vaccine
}

National Cancer Institute

\section{Source}

National Cancer Institute. MELITAC 12.1 Peptide Vaccine. NCI Thesaurus. Code C95741.

A peptide cancer vaccine consisting of an emulsion of a mixture of 12 class I MHCrestricted melanoma peptides and a class II MHC-restricted tetanus toxoid helper peptide, with potential immunostimulating and antineoplastic activities. Upon administration, the MELITAC 12.1 peptide vaccine may stimulate the host immune system to mount a cytotoxic T-cell response against tumor cells expressing the melanoma peptide antigens, resulting in tumor cell lysis. The melanoma peptides contained in the vaccine are upregulated in melanoma cancer cells. 